\title{
Assessment of some Heavy Metals in Muscle Tissue of Silurus triostegus from Derbendikhan Reservoir, Kurdistan Region -Iraq
}

\author{
Rezan O. Rasheed \\ Department of Biology \\ College of Science \\ University of Sulaimani \\ rorasheed@gmail.com ; rezan.rashid@univsul.net \\ (Received 31/3/ 2011; Accepted 5/9/2011)
}

\begin{abstract}
Derbendikhan reservoir is located on the south east of Sulaimani province between longitude $35^{\circ} 6^{\prime} 35^{\prime \prime} \mathrm{N}$ and latitude, $45^{\circ} 41^{\prime} 20^{\prime \prime} \mathrm{E}$, and it is the second largest reservoir in the Iraqi Kurdistan region at an altitude of about $485 \mathrm{~m}$ above sea level. More than twenty genera of fishes are endemic to this reservoir, Silurus triostegus is one of them, which was selected to determine the amount of heavy metals that accumulated in the muscle tissue. The results revealed that the metals were accumulated in the following descending order $(\mathrm{Fe}<\mathrm{Ni}<\mathrm{Cu}<\mathrm{Cd}<\mathrm{Mn}$ ) (i.e) Iron have the highest accumulation rate mean of $5.36 \pm 16.03$ and the Manganese have the lowest rate with the mean of $4.19 \pm .41$ and also, the results revealed that the nourishment behavior was played an important role in the accumulation of these elements in the muscle of Silurus triostegus.
\end{abstract}

Keywords: heavy metals, Derbendikhan reservoir, Silurus triostegus.

\section{قعير بهض المعامن القيلة في النسجة المضلية السمكة Silurus triostegus في خزان

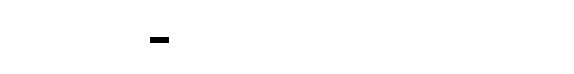

\section{الملغص}

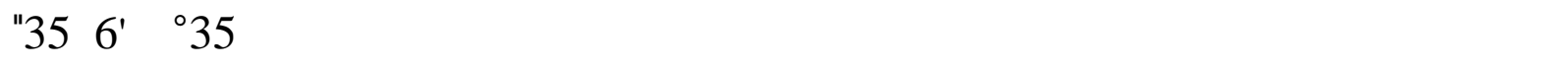
شمالا و 45 "20'41شرقا. وهو ثاني لكبر الخزالنت في كرهستان العراق ويبلغ ارتفاعه فوق مستوى فسطح

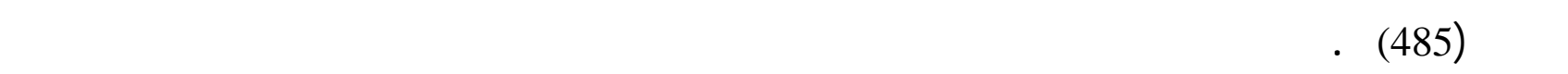
الج _ري Silurus triostegus إحدى هذ الأجناس المختارة لأجل قيلس كمية المعان القيلة الموجونة والمترلكمة في النسج العضلي لها. أظهرت التنائج أن المعانن القيلة قد ترلكمت وفق الترتيب التنازلي التالي فالحيد أبدى أعلى معدل للترلمم فقد كان متوسط الترلكيز 16.03 Fe) 


\section{المنغنيز بمتوسط بلغ 41.4.19. كما لظٔلهرت النتائج أيضا إن طريقة التغنية لعبت دورا مهما في ترلمم المعان القيلة دلخل الأنسجة العضلية للسمكة قيد الدرلسة.}

\section{INTRODUCTION}

It is known that heavy metals are the most important forms of pollution and they may be accumulate in the tissues of fish which are often at the top of the aquatic food chain. Fish may concentrate large amounts of metals from the water and they might be toxic for human consumption (Papagiannis et al., 2004). Heavy metal pollution has become a matter of great concern over the last few decades, due to their hazards to human consumption of fishery resources other than threat to public water supplies, its contamination in water and its uptake by fishes is a direct consequence of urban and industrial pollution, (Chapman, 1996). Domestic wastewater contains substantial quantities of metals. The prevalence of heavy metals in domestic formulations, such as cosmetic or cleansing agents, are frequently overlooked. On the other hand, agricultural discharge contains residual of pesticides and fertilizers, which contains metals. (Baker and Tracy, 2008). Mine runoff and solid waste disposal areas, and, atmospheric pollution like acid rains contain trace metals as well as suspended particulate matter (SPM) input to the water body will cause the pollution of water with metals. (Ondov and Caffrey, 1998 and Wetzel, 2001). Naturally, heavy metal concentrations in the living tissue are low (David and Milne, 1973). Most heavy metals are essential for living organisms like $\mathrm{Zn}, \mathrm{Fe}, \mathrm{Mn}, \mathrm{Cu}, \mathrm{Co}, \mathrm{Mg}$, and $\mathrm{V}$. If they present in a normal range, in case of any fluctuation out of this range will cause many dangerous effects on the activity of these organisms (Ikem et al., 2003). Various aquatic organisms occur in Lakes, potentially useful as biomarkers of metal pollutants, including fish (Hellawell, 1998)

The aim of the present study is to test the hypothesis that the trophic level and the proximity from impacted areas influence levels of contamination and to assess if these species are indicators of large-scale habitat quality.

\section{The study area}

Derbendikhan reservoir is located on the south east of Sulaimani $35^{\circ} 6^{\prime} 35^{\prime \prime} \mathrm{N}, 45^{\circ} 41^{\prime}$ $20^{\mathrm{N}} \mathrm{E}$, and it is the second largest reservoir in the Iraqi Kurdistan region at an altitude of about $485 \mathrm{~m}$ above sea level. (Fig. 1). The main water reservoir of Derbendikhan dam is located on the Diyala Sirwan river approximately $65 \mathrm{~km}$ south- east of Sulaimani Anon, (2006). The climate of the area is Irano - Turanion type, characterized by three seasons: A cold winter, mild growing period of spring and hot- dry summer (Guest, 1966). Mean annual precipitation of $635-700 \mathrm{~mm}$; occur in winter and early spring. 


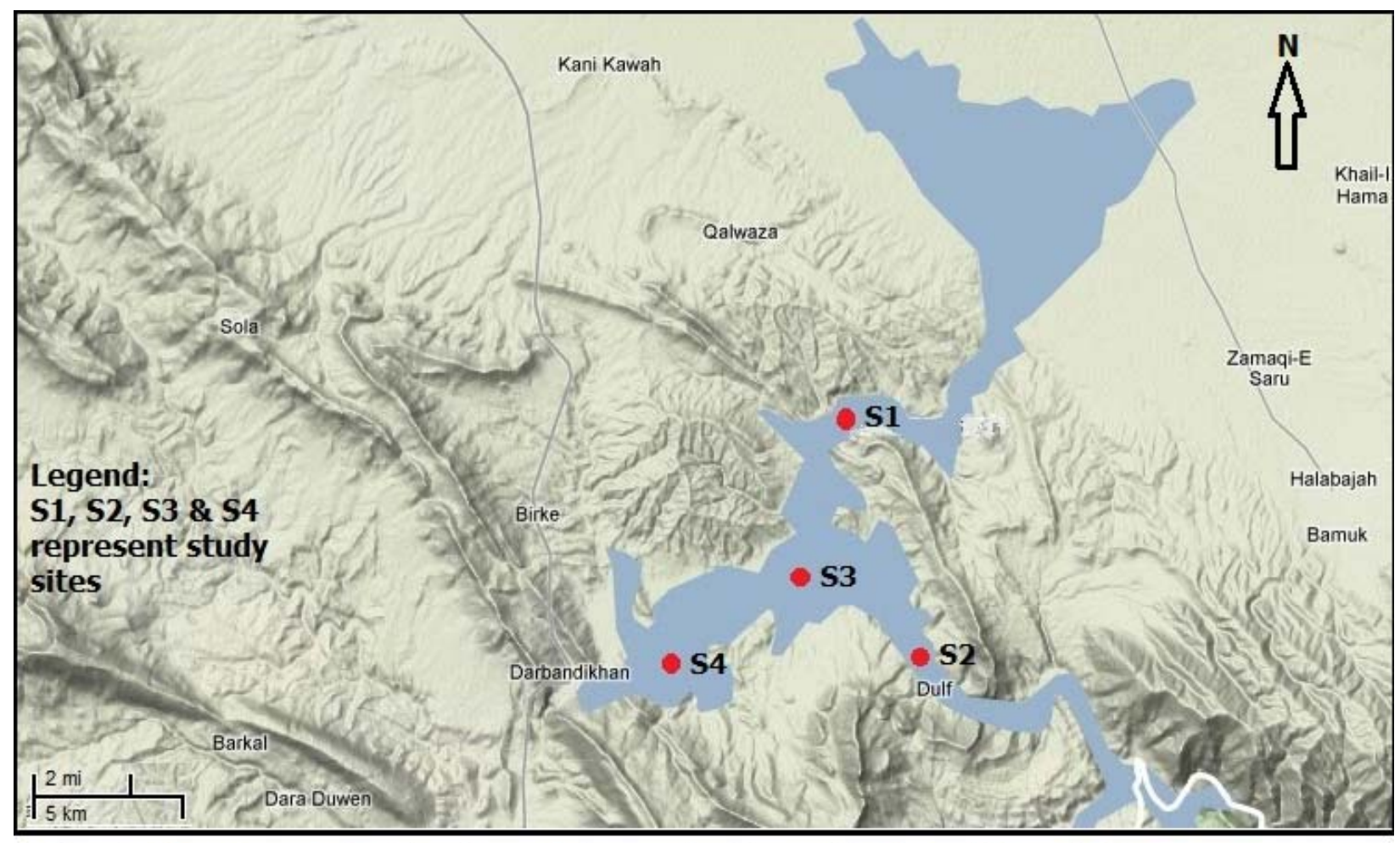

Fig. 1. Map shows the location of the study sites at Darbandikhan Lake.

\section{MATERIALS AND METHODS}

Fish samples were caught from Derbendikhan reservoir from four sites, during the catching season (February-March) of 2011. Gill-nets with different mesh size were used for catching. Samples were iced in straphore boxes, transferred to the laboratory, and their lengths and weights were measured immediately. The length and weight of the samples were shown in (Table 1). Then, the muscles were grounded and frozen stored at $-30 \mathrm{C}^{\circ}$ until time for analysis. Heavy metals in fish were determined by a procedure suggested by (ROPME, 1982), which $1 \mathrm{gm}$ of dried fish was added to a test tube then $1: 1 \mathrm{HClO}_{4}$ (perchloric acid) and $\mathrm{HNO}_{3}$ were added, to the sample for digestion purposes. After leaving the test tube for 1 minute, re heated at $70 \mathrm{C}^{\circ}$ for 30 minutes, and then samples were diluted with de-ionized water, concentration of each heavy metal was determined by using atomic absorption spectrophotometer, with special hollow cathode lamp for each element. The results were statistically analyzed according to the statistical program (SPSS), Version 16. The maximum, minimum, mean, and standard error of each data were calculated. (Al-Rawi and Abdul Al-Aziz, 1985).

\section{RESULTS AND DISCUSSION}

Some biological factors of Silurus triostegus as shown in Table 1, were studied and revealed that the growth of fish was isometric when the value of $b=3$ in this reservoir with the value of $\left(r^{2}\right)$ was 0.65 (Rasheed, 2011). 
The range of maximum and minimum Ni concentration ranged from 59.231 to 33.342 $\mu \mathrm{g} \mathrm{gm}^{-1}$ with the mean of $46.71 \pm 2.60$, while Mn ranged from 6.984 to $2.129 \mu \mathrm{gm}^{-1}$ with

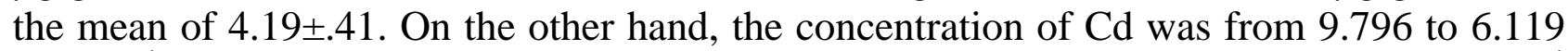
$\mu \mathrm{g} \mathrm{gm}^{-1}$ as the maximum and minimum ranges, with the mean of $8.49 \pm .35 \mu \mathrm{g} \mathrm{gm}^{-1}$ concentration of each of $\mathrm{Fe}$ and $\mathrm{Cu}$ were ranged from 578.928 to $435.123 \mu \mathrm{g} \mathrm{gm}^{-1}$, and 13.3 to $8.24 \mu \mathrm{gm}^{-1}$ as a maximum and minimum values with their mean $5.36 \pm 16.03$ and $10.08 \pm .34$ respectively. Fig. 2,3, Table 2 .

As shown in table 3, bioaccumulation of $\mathrm{Fe}$ was the most abundant element then $\mathrm{Ni}$, $\mathrm{Cu}, \mathrm{Cd}$, and $\mathrm{Mn}$. Abundance may be related to the amount of $\mathrm{Fe}$ in sediment of the reservoir when the sediment concentration of iron was between $6461.25 \mu \mathrm{g}$ g-1 and $6967.812 \mu \mathrm{g} \mathrm{g}^{-1}$ as minimum and maximum values, respectively (Rasheed, 2008). This may be mainly due to the sewage effluents, pesticides and other human activities in addition to the natural sources. (UNEP, 1980). Concentration of $\mathrm{Ni}$ in water ranged between $0.148-$ $3.37 \mathrm{mg} \mathrm{l}^{-1}$ with the mean of $0.215 \mathrm{mg} \mathrm{l}^{-1}-0.69 \mathrm{mg} \mathrm{l}^{-1}$ was recorded during summer and winter respectively, this is out of the range of $0.02 \mathrm{mg} \mathrm{l}^{-1}$ (WHO, 1996). The high Ni concentration in water may be due to the higher amount of hydrocarbon petroleum in the same period (Rasheed, 2008). The Fish liver was the organ that accumulated significantly higher quantities of nickel, followed by that of kidney, gills and muscle. The age and size are other factors affecting the amount of $\mathrm{Ni}$ in tissues as was mentioned by many scientist as Krenkel (1975); Javed (2005).

Generally, the concentration of $\mathrm{Cu}$ was at the minimum value in water samples during catching season because of the high activity of phytoplankton to consume more $\mathrm{Cu}$ in this time, (Rasheed, 2008). Cd is very toxic to fish and other aquatic organisms; however, temperature, $\mathrm{pH}$ and water hardness are factors that influence its toxicity and uptake by fish (Barlas et al., 2005). In the study carried out by (Rasheed, 2008) on Derbendikhan reservoir, it was found that the sediment Cd concentration was high $\left(19.592 \mu \mathrm{g} \mathrm{g}^{-1}-44.082\right.$ $\mu \mathrm{g} \mathrm{g}^{-1}$ ) which is higher than of $0.03 \mu \mathrm{g} g-1$ in sediments of both Shatt Al-Arab River and Khor Al-Zubair (Abychi and Al-Saad, 1988) and $0.002 \mu \mathrm{g} \mathrm{g-}{ }^{1}$ as recorded by (Elmaci et al., 2007), also its concentration will be high in the muscle of study fish because of its feeding type. On the other hand, Mn was the lowest element in this order, it may be due to the feeding type of detritus of the fish, also its an essential plant and animal nutrient and activates several enzyme system, in addition to this, its concentration is very low in both strong acidic and alkaline soils.

Table 1: some biological parameters of Silurus triostegus after (Rasheed, 2011).

\begin{tabular}{|c|c|c|c|c|c|c|c|c|c|}
\hline Fish Species & No. & $\mathbf{a}$ & $\begin{array}{c}\text { Min and } \\
\text { Max length }\end{array}$ & $\begin{array}{c}\text { Median } \\
\text { length }\end{array}$ & $\begin{array}{c}\text { Min and } \\
\text { Max } \\
\text { weight }\end{array}$ & $\begin{array}{c}\text { Median } \\
\text { weight }\end{array}$ & $\mathbf{b}$ & $\mathbf{r}^{2}$ & $\mathbf{K}$ \\
\hline $\begin{array}{c}\text { Silurus } \\
\text { triostegus }\end{array}$ & 30 & 0.11 & $24-63$ & 30 & $250-2500$ & 288 & 3 & 0.65 & 1.07 \\
\hline
\end{tabular}

weight in gm ; length in cm ; No, sample's number; a, intercept of the relationship; b, slope of therelationship $; \mathrm{r}^{2}$,coefficient of determination . K, condition factor 


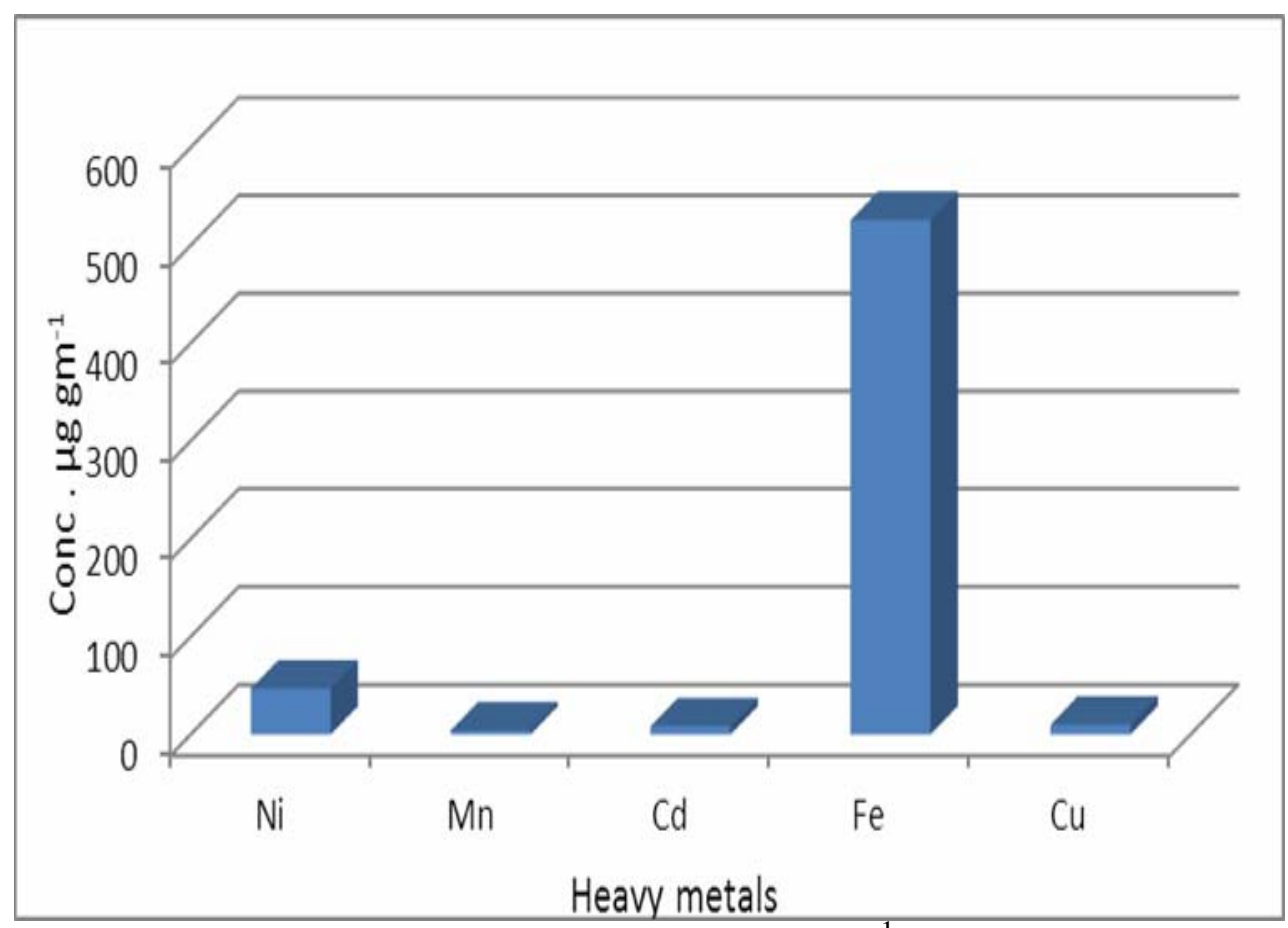

Fig. 2: Mean concentrations of heavy metals in $\mu \mathrm{g} \mathrm{gm}^{-1}$ muscle tissue of Silurus triostegus.

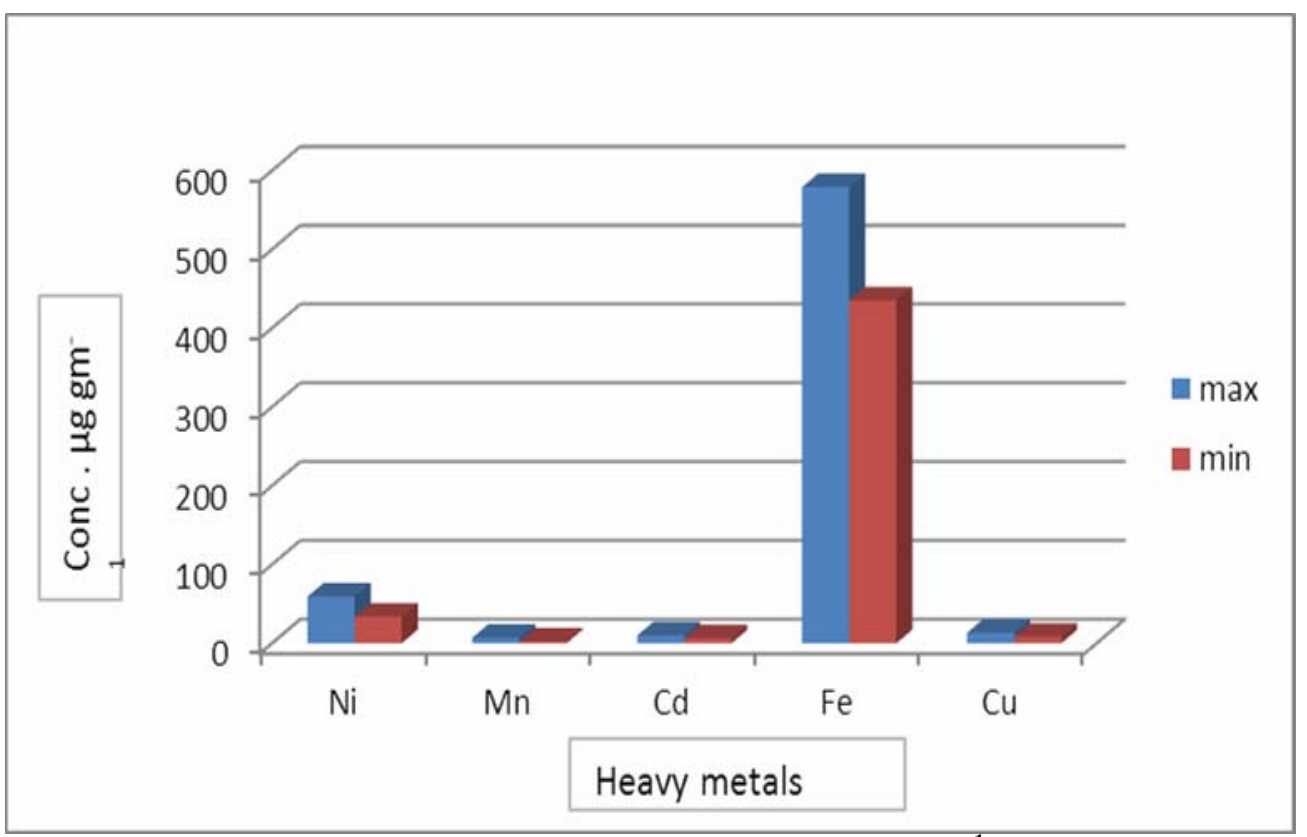

Fig. 3 : Maximum and minimum concentration in $\mu \mathrm{g} \mathrm{gm}^{-1}$ of heavy metals in muscle tissue of Silurus triostegus 
Table 2 : Statistical Description for heavy metals in fish muscle.

\begin{tabular}{|c|c|c|c|c|}
\hline Heavy metals & $\mathbf{N}$ & $\begin{array}{c}\text { Minimum } \\
\mu^{\prime} g^{-1}\end{array}$ & $\begin{array}{c}\text { Maximum } \\
\mu \mathrm{g} \mathrm{gm}^{-1}\end{array}$ & Mean \pm Std. Error \\
\hline $\mathrm{Ni}$ & 15 & 33.432 & 59.231 & $46.71 \pm 2.60$ \\
\hline $\mathrm{Mn}$ & 15 & 2.129 & 6.984 & $4.19 \pm 0.41$ \\
\hline $\mathrm{Cd}$ & 15 & 6.119 & 9.796 & $8.49 \pm 0.35$ \\
\hline $\mathrm{Fe}$ & 15 & 435.12 & 578.928 & $5.36 \pm 16.03$ \\
\hline $\mathrm{Cu}$ & 15 & 8.24 & 13.30 & $10.08 \pm 0.34$ \\
\hline $\begin{array}{l}\text { Valid N } \\
\text { (list wise) }\end{array}$ & 15 & & & \\
\hline
\end{tabular}

Table 3 : Concentration series for heavy metals in muscle tissue of Silurus triostegus.

\begin{tabular}{|c|c|}
\hline Species & Order of bioaccumulation \\
\hline Silurus triostegus & $\mathrm{Fe}<\mathrm{Ni}<\mathrm{Cu}<\mathrm{Cd}<\mathrm{Mn}$ \\
\hline
\end{tabular}

\section{CONCLUSIONS AND RECOMMENDATIONS}

1. Prevent using of fertilizer by farmers, particularly near the reservoir.

2. The fish muscle contains high amounts of heavy metals as a result of bioaccumulations and biomagnifications of them.

3. Treatment of the sewage before its discharge into the reservoir by building a waste water treatment plant.

4. More studies for more characters in water, fish and sediment in detail and time interval, are necessary for this lake as a water-monitoring program.

5. Growing vegetation near the shore, around the reservoir, to prevent erosion of the soil into the water.

6. Preventing usage of older boats so as not to increase the amount of chemicals introduced to the lake.

7. More attention must be pay to increase the fish productivity by fish management must be done for preceding the economy in the area. 


\section{REFERENCES}

Abaychi, J. K.; Al-Saad, H. T. (1988). Trace elements in fish from the Arabian Gulf and Shatt Al-Arab river, Iraq. Bullt. Environ. Contam. Toxico, 40, 226-232.

Al-Rawi, Kh. ; Abdul Al-Aziz, M. (1985). Design and analysis of agricultural experimental Higher Education and Scientific Research Ministry, University of Mosul. Book house Organization for Printing and Publishing. (in Arabic).

Anon, (2006). The World Bank, Dokan and Derbendikhan Emergency Hydropower. Consultancy Services for Dokan and Derbendikhan Dam Inspections, Inspection report (Final), E1537. SMEC. Section A - Complementary Grouting in Dam, Derbendikhan Dam main remedial works (Phase 1), analysis of Dam behavior, review of previous reports recommendations, Coyne Bellier, May 1975.

Baker, B.; Tracy, D. (2008). Elemental contaminants in fertilizers and soil amendments used in organic production.16th IFOME organic world congress, Modena, Italy. archived in http://www.orgprints.org. 14829.

Barlas, N.; Akbulut, N.; Aydo_an, M. (2005). Assessment of heavy metal residues in the sediment and water samples of Uluabat Lake, Turkey. Bull. Environ. Contam. Toxicol. 74, 286-293.

Chapman, D. (1996). "Water Quality Assessments-A Guide to the Use of Biota, Sediment and Water in Environmental Monitoring". 2nd edn., London: E and FNS pon., 626 p.

David, H. A. ; Milne, M. (1973). "Clinical Chemistry", 2nd edn., Chicago, Illinois: 1319 p. Elmaci, A.; Teksoy, A.; Topaç, F. O.; Özengin, N.; Kurto_lu, S.; Sava_Ba_kaya, H. (2007). Assessment of heavy metals in lake Uluabat, Turkey. Uluda University, Faculty of Engineering and Architecture, department of Environmental Engineering, görükle, Bursa 16059, Turkey, African J. Biotech., 6(19), 2236-2244.

Guest, E. (1966). " Flora of Iraq". Ministry of Agriculture, Baghdad, 1, 213 p.

Hellawell, M. J.(1998). Toxic substances in rivers and streams, Environ. Pollut. 50, 61-85.

Ikem, A.; Egıebor, O.; Nyavor, K. (2003). Trace elements in water, fish and sediment from Turkegee lake, South eastern USA. Water, Air Soil Pollut. 149, 51-75.

Javed, M. (2005). Heavy metal contamination of freshwater fish and bed sediments in the river Ravi Stretch and related tributaries. Pakis. J. Biol. Sci. 8(10), 1337-1341.

Krenkel, P. A. (1975). "Heavy Metals in the Aquatic Environment". Pergamon Press. Oxford, New York., 352 p.

Ondov, J. M.; Caffrey, P. F. (1998)." Deposition of toxic trace elements and heavy metals into lake Michigan by size and by source". Department of Chemistry. University of Maryland. College Park, MD, 20742 p.

Papagiannis, I.; Kagaloub, I.; Leonardos, J.; Petridis, D.; Kalfakakou, V. (2004). Copper and zinc in four freshwater fish species from lake Pamvotis (Greece). Envir. Internat., 30, 357-362.

Rasheed, R.O. (2008). Evaluation of heavy metals and polyaromatic hydrocarbons in water, fish, and sediments within Derbendikhan reservoir, Ph.D. Thesis, Univ. of Sulaimani, Sulaimani, Iraq., 138 p.

Rasheed, R.O.(2011). Length-Weight relationships of 9 fish species from Derbendikhan reservoir-Kurdistan region, Iraq. J. Babylon Univ. 20(2), (In press) 
Regional Organization for the Protection of the Marine Environment (ROPME), (1982). Manual of Oceanographic Observation and Pollution Analysis Methods ROPME/ P. O Box 16388. BlZusafa, Kuwait.

United Nation Environmental Protection Agency (UNEP), (1980). " Storm Drain Outfalls and Solid Waste Landfills". UNEP, Geneva , 56 p.

Wetzel, R. G. (2001). "Limnology. Lake and River Ecosystems". 3rd edn. Academic press, Elsevier Science Imprint, San Francisco, New York, and London.

World Health Organization (WHO), (1996). "Guidelines of Drinking Water Quality". 2nd edn. 2. Geneva, $24 \mathrm{p}$. 